DOI https://doi.org/10.18551/rjoas.2016-11.04

\title{
STRUCTURE, CONDUCT AND PERFOMANCE OF THE RICE MARKET IN NORTH-WEST REGION OF CAMEROON: A DESCRIPTIVE ANALYSIS
}

\author{
Bime M.J. ${ }^{*}$, Mai Bong J.K., Manu I. \\ University of Dschang, Cameroon \\ ${ }^{*}$ E-mail: mimeliet001@yahoo.com
}

\begin{abstract}
This study carried out in the Menchum River valley, Northwest Region of Cameroon, in the year 2013 had as objective to analyze the structure, conduct and performance of the rice market in this zone. The study interviewed a total of 92 respondents (75 farmers-traders, 3 millers, 4 wholesalers and 10 retailers) who were selected purposively. The analysis of the results showed that the main actors involved in the rice market were: farmers-producers, wholesalers, millers and retailers. The males generally dominate in the rice trade particularly wholesaling $(80 \%)$, milling $(100 \%)$, while women dominate in the retail business $(70 \%)$. The millers and the wholesalers are the principal buyers of farmers' produce (paddy). The rice market is oligopolistic in nature, prices are determined mainly by the forces of demand and supply and it equally does not satisfy customer desires or requirements. The millers obtained the highest margins amongst the trader. In terms of equity, the margins vary from one actor of the market to the other with the miller getting the greatest share and closely followed by the farmer. The principal constraints identified by the study that affects actors of the rice market were, bad farm to market roads, lack of capital, poor quality of rice and the insufficient improved seeds for farmers as well as poor selling methods. The recommendations at the end of this study are centered mainly on enhancing production and productivity, facilitating extension services and enhancing marketing.
\end{abstract}

\section{KEY WORDS}

Structure, conduct, performance, rice, market.

The global market for rice is thin. The international rice market represented only 3-5 per cent of global production in the 1980 s, but it has come to $7 \%$ of global production in recent years. Nevertheless, the international rice market remains thin compared to wheat $(18 \%)$ and maize (13\%). Thailand, India, Vietnam and the United State are the top four exporting countries of rice supplying $66 \%$ of trade (World Rice Research Conference, 2004). The most important change in the world rice market during the past fifty years has been the dramatic decline in the level of prices adjusted for inflation (David \& Slayton, 2004). It was found that world rice prices were $77 \%$ lower than the average from 1950-1981. The main factor behind this decline in prices was the Green Revolution, which led to an increase in yield and a lowering of unit production cost. World rice prices are also much more stable. The average absolute value of annual price changes was $24 \%$ between 1965 and 1981 and it was 11 per cent between 1985 and 1998 (David \& Slayton, 2004). Increased production stability and pronounced deepening of the world market are contributing factors for price stability.

The production of rice in sub-Saharan Africa has steadily increased since the 1970s, reaching almost 7 metric tons $(\mathrm{Mt})$ of milled rice as at the end of the last decade. The increase in rice production of about $70 \%$ is due to expansion in area of cultivation and 30 percent due to yield increase (Fagade, 2000; Falusi, 1997). The gap between rice demand and regional supply is however increasing; in 1998 it was about 4 Mt of milled rice for subSaharan Africa as a whole. Lançon and Erenstein (2002) showed that despite withdrawal of fertilizer subsidies and reforms of rural credit banks, rice profitability in West and Central Africa has improved in recent decades. Using the Domestic Resource Cost (DRC) ratio as an indicator, rice competitiveness for most West and Central African countries shows an upward trend. Rice demand in sub-Saharan Africa has been growing rapidly since the mid 
1970s. The average growth of rice consumption is now more than 6 percent per year and amounts to over 10 million tons (Mt) of milled rice per year. This increase is due to population growth (2.6\% per year) and the increasing proportion of rice in the African diet (1.1\% per year, i.e. $30 \mathrm{~kg}$ per caput per year in 1998 (FAO, 1999)) - a result of the rapid urbanization process (Snrech, 1994)

Agricultural marketing is the main driving force for economic development and has a guiding and stimulating impact on production and distribution of agricultural produce. The increasing proportion of the population living in urban centers and the rising level of income in Cameroon and most African countries require more organized channels for processing and distributing agricultural products. The weak performance of agricultural markets (both input and output markets) in most African countries has been recognized in various studies as a major impediment to growth in the agricultural sector and the overall economy (Dawit, 2005 cited in Astewel 2010). Improving marketing facilities for agricultural crops in general and rice sector in particular enable farmers to plan their production more in line with market demand, to schedule their harvests at the most profitable times, to decide which markets to send their produce to and negotiate on the best possible price with traders. Besides, a proper rice marketing system is also essential as it leads to increase production and market efficiency.

However, the nature of the product on the one hand and the lack of organized market system on the other have resulted in low producers' price. Besides, there are other challenges associated with rice production and marketing mainly on Knowledge of grading, market information, excessive intermediaries, price seasonality, limited number of buyers, and lack of markets.

Structure, conduct, and performance (SCP) analysis was developed by Bain (1968). This theory explains that the market structure (the environment) determines market conduct (the behavior of economic agents within the environment) and thereby sets the level of market performance. It is an attempt to compromise between formal structures of economic theory and empirical observations of organizational experience in imperfect markets. It is a standard tool for market analysis (Duc Hai, 2003). SCP is an analytical approach or framework used to study how the structure of the market and the behavior of sellers of different commodities and services affect the performance of marketing, and consequently the welfare of the country as a whole (Kizito 2008). The definition of structure, conduct and performance differs from one author to the other, depending on the sector and region being studied and the perception of the researcher. According to Tesfaw and Alemu (2013) improving the market environments should be a priority for improving the supply and satisfying the demand of the commodity. Investigation of the system in terms rice market structure, conduct and performance and institutional support services taking in to consideration the product and location specificity used to identify the restricting factors and come up with specific possible solutions of the study area. The study had as objective to analyze the market structure, performance and conduct of rice market, as well as to identify the constraints and opportunities in production and supply.

\section{RESEARCH METHODOLGY}

This study aimed at analyzing the structure, conduct and performance of the rice market was carried out in the North West Region (precisely in the Menchum River Valley) of Cameroon in the year 2013. This region is one of the ten regions that make up the country and is characterised by a temperate climate with an abundance of rivers and valleys that favour and promote rice cultivation. The study used both primary and secondary data collected from respondents using questionnaires and interview guide. A multi-stage sampling technique was used to randomly select the respondents. The market centres were first identified and then from each centre the intermediaries (farmer traders, wholesalers, millers and retailers) were selected based on the proportion of traders in each centre. A sample size of 92 intermediaries ( 75 farmers-traders, 4 wholesalers, 3 millers and 10 retailers) was finally got from three market centres. 
The data collected was analyzed using descriptive and inferential statistics. The descriptive statistics used includes frequency distribution, means and percentages. The structure of the marketing system was evaluated in terms of the degree of market concentration (buyers and sellers), barrier to entry and the degree of transparency, degree of product differentiation as well as market knowledge of the participants involved. The Market conduct was analyzed relative to the set of competitive strategies that a trader or a group of traders use to run their business. In other words, market conduct focuses on traders' behavior with respect to various aspects of trading strategies such as buying, selling, transport, storage, information and financial strategy. Performance being a consequence of structure and conduct defined the strategy and end results of market adjustments engaged in by the actors. The major indicators of market performance which this study made use of were marketing cost, returns and marketing margins of the actors. Other performance measures included, profits level, technological progressiveness, efficiency, product improvement.

\section{RESULTS AND DISCUSSIONS}

Characteristics of rice traders. According to results obtained, four main actors who intervene in the marketing of rice were identified in the study area. These handle the commodity at different levels of the transaction. The results revealed that males generally dominate in the rice trade particularly wholesaling $(80 \%)$, milling $(100 \%)$, while women dominate in the retail business (78.6\%). The millers and the wholesalers are the principal buyers of farmers' produce (paddy).

Table 1 - Characteristic of the sampled respondents

\begin{tabular}{|c|c|c|c|c|c|c|c|}
\hline \multicolumn{2}{|c|}{ Characteristics Of Respondents } & \multirow{3}{*}{$\begin{array}{c}\text { Miller } \\
0 \\
4\end{array}$} & \multirow{3}{*}{$\begin{array}{c}\text { Wholesaler } \\
1 \\
2\end{array}$} & \multirow{3}{*}{$\begin{array}{c}\text { Retailer } \\
7 \\
3\end{array}$} & \multirow{3}{*}{$\begin{array}{c}\text { Farmer } \\
\text { trader } \\
15 \\
60\end{array}$} & \multirow{3}{*}{$\begin{array}{c}\text { Total } \\
23 \\
69\end{array}$} & \multirow{3}{*}{$\begin{array}{c}\text { Percentage } \\
25 \\
75\end{array}$} \\
\hline Gender & Female & & & & & & \\
\hline Status & Male & & & & & & \\
\hline \multirow{4}{*}{ Marital Status } & Single & 1 & 0 & 3 & 9 & 13 & 14.13 \\
\hline & Married & 3 & 3 & 6 & 63 & 75 & 81.53 \\
\hline & Divorced & 0 & 0 & 1 & 1 & 2 & 2.17 \\
\hline & Widow & 0 & 0 & 0 & 2 & 2 & 2.17 \\
\hline \multirow{4}{*}{$\begin{array}{l}\text { Level Of } \\
\text { Education }\end{array}$} & Informal & 0 & 0 & 1 & 8 & 9 & 9.78 \\
\hline & Primary & 3 & 2 & 5 & 54 & 64 & 69.56 \\
\hline & Secondary & 1 & 1 & 4 & 7 & 13 & 14.13 \\
\hline & Tertiary & 0 & 0 & 0 & 6 & 6 & 6.53 \\
\hline \multirow{5}{*}{ Age } & $21-30$ & 1 & 0 & 1 & 4 & 6 & 6.53 \\
\hline & $31-40$ & 0 & 0 & 2 & 13 & 15 & 16.30 \\
\hline & $41-50$ & 2 & 2 & 4 & 47 & 55 & 59.78 \\
\hline & $51-60$ & 1 & 1 & 3 & 7 & 12 & 13.04 \\
\hline & $61-70$ & 0 & 0 & 0 & 4 & 4 & 4.35 \\
\hline House Hold & $0-10$ & 3 & 2 & 6 & 22 & 33 & 35.87 \\
\hline Size & $>11$ & 1 & 1 & 4 & 53 & 59 & 64.13 \\
\hline Main & Agric & 1 & 0 & 3 & 63 & 67 & 72.83 \\
\hline Occupation & Trade & 3 & 3 & 7 & 12 & 25 & 27.17 \\
\hline \multicolumn{2}{|c|}{ Total Per respondent category } & 4 & 3 & 10 & 75 & 92 & 100 \\
\hline
\end{tabular}

Source: Data Survey, 2013.

Man being at the centre of this study, it was therefore important to show how the social indicators affect the activities. Table 1 therefore summarizes the characteristics of the actors that were interviewed for this study. It presents a profile of rice farmer-traders, millers, wholesalers, and retailers in terms of gender, age, marital status, level of education and main occupation The age of the household is considered a crucial factor, since it determines whether the household benefits from the experience of an older person, or has to base its decisions on the risk-taking attitude of a younger farmer. Descriptive statistics showed that the age of the respondents ranged from 22 to 70, with a minimum of 22 (youngest) and a maximum of 70 (oldest) with an average age of 45.12 years. This is therefore an indication 
that rice marketing in the zone is handled mostly by experienced middle aged citizen who still have energy for work and are very daring when it comes to risk taking. Hence they may be very easy to convince when it comes to adopting an innovation. The study further shows that $35.87 \%$ of the respondents had a family size of less than or equal to 10 members while $64.13 \%$ had a family size greater than 11 members. The larger family sizes at the same time increase the number of mouths to feed and equally act as labor force. The results are similar to that of Akarue and Ofoegbu (2012) who had 4-6persons per household in Nigeria as the majority $(48.57 \%)$ of the respondents. Base on the results it can be said that the main occupation of majority of the actors was agriculture as the result show that, $72.83 \%$ of them were mainly farmers while others were involved in businesses, such as trade and other activities.

\section{Structure of the rice market.}

In order to evaluate the market structure of rice, the following indicators were used in the study:

The number and relative size of buyers and sellers concentration: the rice market here is oligopolistic in nature as it is characterized by a few buyers and sellers. Few sellers are involved in the rice business (oligopoly). On the buying side of the transaction, the rice market here is equally characterized by few buyers (oligopsony).

Market knowledge: majority of farmers and some trader do not have any access to any information of any kind be it in terms of price in different markets and quality/quality or actions that competitors take as well as future market conditions. Hence most at time prices are determined by forces of demand and supply.

Barriers to entry into the rice market: the barriers to entry into the market reflect the competitive relationships between existing traders and potential entrants. The rice market here is characterized by few actors each anticipating the other's reaction thereby making entry into the market very difficult and even in a few cases, virtually impossible. The survey result indicated that various barriers to entry into the rice business identified by the traders (wholesalers and millers) were: lack of investment capital, high competition with prior control of farmers, information asymmetry and severe competition among traders. Capital is the main barrier to entry into the rice market here. They need much capital to purchase more rice especially during harvesting (peak purchase) time. They usually do not allow farmers go without purchasing the available amount of rice they brought. When this happens, they lose their customer at least for some time.

Degree of product differentiation: most buyers feel the rice of one seller from this zone is virtually no different from those of other sellers. Hence, since buyers believe rice is not different in quality and in their eyes, a farmer or trader of rice from this zone finds it difficult to convince buyers that his/her rice is different from the others.

Experience and education levels of rice wholesalers and millers: the survey results indicates that for millers who are both into milling and wholesales $50 \%$ of them have an experience in rice trading ranging between 5 to 10 years, while the remainder $50 \%$ of them had experience >10years. With regard to their education level, about $71.43 \%$ had at least primary education and $28.57 \%$ had at least a secondary level of education. This indicates that education is not a constraint to rice trading activity because majority of rice traders have had formal education. Hence it's an added advantage to them as they can easily and better access market information (with respect to demand and supply) as well as bargain to maximize their profits.

Conduct of the rice traders.

Purchasing strategy: the purchasing strategy for wholesalers revealed that majority of the sampled wholesalers do their purchase based on; long term client establishment, intra family link, spontaneous purchasing, and lastly they purchase without a median agent. A few purchase on contract basis (install mental payment especially for regular customers), or using a combination of any of the aforementioned methods. Nevertheless the most common form of payment in all these purchasing strategies is liquid cash. 
Pricing strategy: about $50 \%$ of the sampled traders indicated that price is set by the market (i.e. forces of demand and supply), while $30 \%$ of these traders set the prices themselves, another $15 \%$ set prices based on negotiating power of the buyers and traders.

Transport means: transportation of the paddy upon harvest is mostly done by head load at the level of the farmer when it comes to taking the product home from the farms. Bikes are then generally used to transport the paddy to the mills or market due to bad state of roads which do allow vehicle to reach the farms or interior villages. Big traders on their part use vehicles general known here as cargo to transport rice.

Promotion and stocking: farmers generally do not store their harvest for long. Majority sell immediately after harvest and in some cases even before the rice matures. Wholesalers and millers store the rice relatively longer than the farmers depending on their location and the market demand. Promotion strategies used by farmers include trade discounts, friendly attitudes and credits to customers. The prevailing strategy used here was friendly attitudes followed by selling on credits.

Market performance.

Profits levels and efficiency: the production and marketing of rice in the zone is a profitable venture. In terms of profitability in the rice business, millers obtain a relatively large profit margin as a percentage of the cost price $(18.69 \%)$ followed by the producers $(12.77 \%)$, wholesalers $(8.5 \%)$ then retailers $(8.33 \%)$. The average profit margin obtained by the producers per hectare was about 134484,90 FCFA, the average profit margin per bag of $50 \mathrm{~kg}$ was; 1054.5FCFA for producers, 1963.5 FCFA for millers; 1100 FCFA for the wholesalers and 1250FCFA for the retailers. Though the rice business makes profits, analysis have equally shown in this study that the venture is not very efficient when profit earn is compared to the revenue or total cost invested.

Marketing cost and margin analysis of rice traders: it can be seen from these figures that millers receive highest margins while producers lowest margins amongst actors but incure the highest marketing cost. The difference of margins per actor per bag of $50 \mathrm{~kg}$ in the channel considered showed that millers earn 713.5frs more than retailers who in turn earn 150 frs more than wholesalers while wholesalers earn 45.5 frs more than farmers who receive the lowest margins per bag of $50 \mathrm{~kg}$.

MARGINS / 50KG

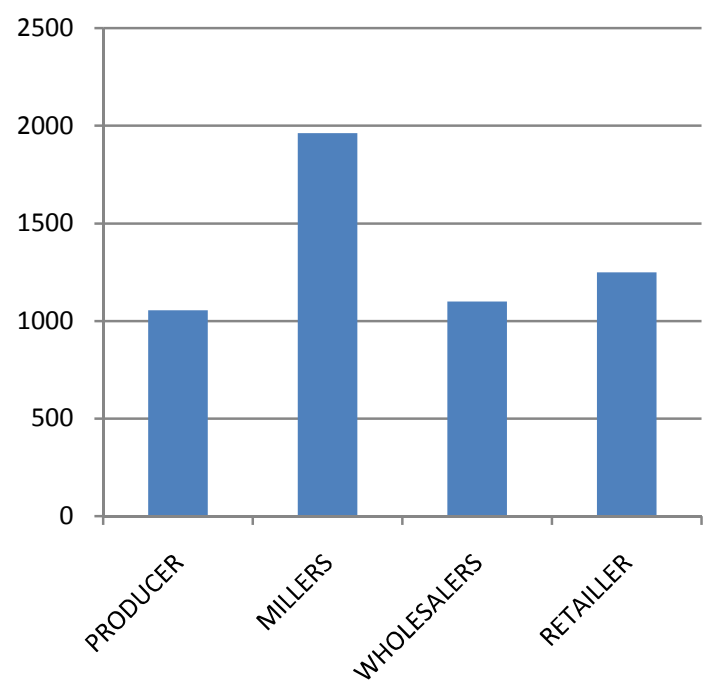

a
MARKETING COST/50KG

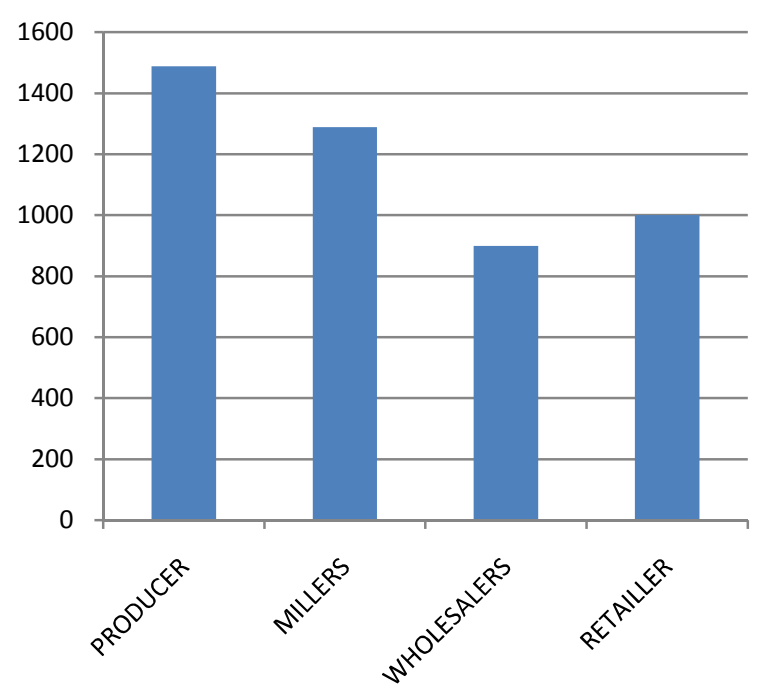

b

Figure $1(a, b)-$ Marketing Margins and cost Per Actor

The millers are better off than all other actors, while farmers are better off when they sell directly to consummers. These results are directly in line with the findings of Tesfaw and 
Alemu, (2003) who in a similar study showed that highest gross marketing margin was made by processors $(70.83 \%)$ and the lowest by farmer traders $(5.5 \%$ of the consumers' price). These results are on the other hand different from the findings of Astewel, (2010) who found in a similar study in Ethiopia that farmers received the highest $10.22 \%$, followed by retailers 6.37 , wholesalers 1.28 and millers $0.8 \%$, in terms of profit margin to cost.

Technological progressiveness and product improvement: results reveal that the rice market in the zone is still lagging behind relative to other rice producing areas in terms of technological advancement. Producers and traders here lack appropriate and adapted hullers, packaging equipments, and parboiling facilities which can improve the quality of their product. This greatly affects the performance of the rice market.

Constraints faced by the actors in production and marketing.

Improved varieties: results showed that, lack of improved varieties was the main constraints for the farmers. Most farmers cultivate the local Variety which is relatively less yielding compared to improved variety, while a few are already planting the improved variety, (NERICA) recently introduce by PADFA though it is still to gain grounds in the zone. It has not yet been widely disseminated for use to farmers.

Lack/absence of good processing machines: problems of processing machines were acknowledged by $55.8 \%$ of the farmers. The absence and the poor state of the few available hulling machines have a negative effect on the quality of rice marketed. The few available machines identified were old, outdated and produce very poor results in term of the break rates of the rice hulled.

Malpractice in selling method (Scaling or Weighing): though respondents were not complaining, may be due to the fact that they were ignorant, a few were aware but said they had no choice. Malpractices of different types such as scaling or weighing, deduction, and quoting of lower prices than actual prices are rampant in the locality. In this study we found out that the bags of paddy which is assumed to be $100 \mathrm{~kg}$ actually weighs between 120 to $150 \mathrm{~kg}$ when properly filled. Hence the farmers are cheated by at least 15 to $20 \mathrm{~kg}$ per bag sold (i.e. $13-16.6 \%$ of their yield).

Marketing of the produce: about $33 \%$ of respondents reported that there were some marketing problems associated with low output price, maintenance of standards and grades. For Example, during husking, grains are broken due to the traditional method of threshing used by farmers (i.e. by beating with stick) and these broken grain decreases market demand.

Lack of information exchange: poor contact or communication was also one of the problems reported by most if not all of the farmers and some traders (27.27\%). Information on market price, demand and supply was also mentioned as a problem by sampled households as majority of farmers do not have access to market information and this negatively affect their market performance.

Transportation problem: more than $47 \%$ of the sampled farmers/traders were unanimous to the fact that the problem of accessibility, both to their farms and to the market was a problem to their activity as a result of the bad state of seasonal roads in the zone.

Lack of capital and credit availability: lack of capital and credit availability was stated by $45.4 \%$ and $39.9 \%$ of respondents respectively as being constraints to production and marketing of rice. Farmers usually have an urgent need for money immediately after harvest. Even though the price of paddy is always at lowest during those period, farmers badly needed cash in order to pay their rent and debts as well as to buy certain necessities. Thus most of the time, lack of post-harvest credit forces farmers to sell their produce immediately after harvest at low prices. These findings are similar to those of Gamawelagedara et al who found out that lack of capital, dearth of storage facilities and highly volatile paddy price were some of the constraints faced by actors in rice production and marketing in Sri Lanka.

\section{CONCLUSION}

The study aimed at describing the rice market structure, conduct and performance was carried out in the North West region, Cameroon. The actors involved in rice marketing are 
the farmer-trader, millers, wholesalers and the retailers. The rice market in this area is oligopolistic in nature with very low level of product differentiation and the absent of market information. Prices are determined mainly by the forces of demand and supply; others negotiate, while some traders set the prices themselves. The market is still lacking behind in terms of technological advancement. Farmers and traders face problems of lack of improved varieties, malpractice in selling methods, transportation problems and lack of capital and credit availability. Based on these findings the following is recommended; intervention to increase production and productivity of rice by providing improved seed varieties; develop infrastructure especially roads and facilitating extension services which will help improve the marketing of the product.

\section{REFERENCES}

1. Akarue, O.B. and S. Ofoegbu. 2012. Marketing analysis of rice in Udu Local Government Area of Delta State, Nigeria. Continental J. Agricultural Economics. 6 (2): 21-31.

2. Astewel. 2010. Analysis of rice profitability and marketing chain: The case of Fogera Woreda, south gondar zone, Amhara national regional state, Ethiopia. An M.Sc Thesis Presented to the School of Graduate Studies of Haramaya University. Pp 1-56.

3. Bain, J.S. 1968. Industrial Organization, 2nd Edition, John Wiley, New York

4. David, D., and T. Slayton. 2004. Change structure, conduct and performance of the world rice market. A paper presented at the FAO rice conference, Rome, 12-13 February 2004

5. Duc Hai, L.T. 2003. The Organization of the Liberalized Rice Market in Vietnam. PhD thesis presented to the University of Groningen, Netherlands.Pp 1-248

6. Fagade, S.O. 2000. Yield gaps and productivity decline in rice production in Nigeria. In Proceedings of the Expert Consultation on Yield Gap and Productivity Decline in Rice, 57 Sept. 2000, FAO, Rome.

7. Falusi, A.O. 1997. Agricultural development and food production in Nigeria: problems and prospects. In Shaib, B., Adedipe, N.O., Aliyu, M. \& Jir, M. eds. Integrated agricultural production in Nigeria: Strategies and mechanisms. NARP Monograph No. 5. p. 151-170.

8. Food and Agriculture Organization (FAO). 1999. FAO-agrostat. Rome. Italy.

9. Gamawelagedara, W.C., Y.M. Wickramasinghe., and C.A.K. Dissanayake. 2011. Impact of rice processing villages on household income of rural farmers in Anuradhapura district. The J of Agric Sc, 6(2) 92-99.

10. Kizito, A. 2008. Famine early warning systems net work (FEWS NET): market Guidance No.2. Structure -Conduct -Performance and food security. Retrieved from http//www.fews.net. Pp 1-18.

11. Lançon, F. and O. Erenstein. 2002. Potential and prospects for rice production in West Africa. Paper presented at Sub-Regional Workshop on Harmonization of Policies and Co-ordination of Programmes on Rice in the ECOWAS Sub-Region, Accra, Ghana, 2528 Feb. 2002.

12. Snrech, S. 1994. Pour préparer l'avenir de l'Afrique de l'Ouest: une vision à l'horizon 2020. Synthèse de l'étude. SAH/(94)439. Cellule CINERGIE. Club de Sahel. Paris, France.

13. World Rice Research Conference Report. (2004) 